\title{
ANALISIS DAYA TAHAN MAHASISWA DALAM MELANJUTKAN STUDI DENGAN CHI-SQUARED AUTOMATATIC INTERACTION DETECTION
}

\author{
Lely Kurnia \\ Jurusan Tadris Matematika, Fakultas Tarbiyah dan Ilmu Keguruan, IAIN Batusangkar \\ Jl. Sudirman No. 137 Kuburajo Lima Kaum Batusangkar 27213 \\ Email:yen_lely@yahoo.com
}

\begin{abstract}
This research studies the stuctural interaction between variables that become characteristics or factors affecting durability for students to continue their studies. In this study, the data used are the characteristics of students in the form of data counting and categories so that statistical methods used was CHAID analysis. Dendogram CHAID showed that the variables having strongest association with the durability for students to continue their studies is the mark of Calculus I subject. CHAID method to the analysis of durability for students to continue their studies produced three segments. The first segment is the students who retook the Calculus I subject, the second one is the students who passed or failed in Calculus I subject with semester $1 \mathrm{GPA}<3.00$ and the last is the students who passed or failed in Calculus I subject with semester 1 GPA $>3.00$.
\end{abstract}

Key words: Chi-Squared Automatatic Interaction Detection Analysis (Chaid), Student

\section{PENDAHULUAN}

Peningkatan kualitas lulusan diperguruan tinggi sangat bergantung pada tiga faktor utama yaitu input (calon mahasiswa), proses pendidikan dan kompetensi lulusan. Pada dasarnya perguruan tinggi berusaha semaksimal mungkin untuk meningkatkan lulusannya baik secara kualitas maupun secara kuantitas. Secara kuantitas maksudnya jumlah mahasiswa yang masuk atau terdaftar sama dengan jumlah mahasiswa yang lulus, berarti tidak ada yang drop out maupun mengundurkan diri. Secara kualitas, diharapkan mahasiswa lulus dengan Indeks Prestasi kumulatif yang maksimal dan lulus tepat waktu. Mahasiswa yang berhenti merupakan salah satu cerminan dari tingkat kegagalan suatu perguruan tinggi khususnya jurusan. Mahasiswa yang berhenti studi menjadi masalah tersendiri baik bagi jurusan maupun bagi perguruan tinggi, karena ini akan memberikan dampak negatif terhadap kualitas suatu jurusan. Oleh karena itu perlu dilakukan kajian terhadap faktor-faktor yang signifikan mempengaruhi berhentinya studi mahasiswa sehingga dapat dijadikan informasi yang bermanfaat bagi keberhasilan pendidikan.

Tulisan ini merupakan lanjutan penelitian mengenai faktor-faktor yang mempengaruhi berhentinya studi mahasiswa, hasil penelitian menunjukkan jurusan pada sekolah menengah dan Indeks Prestasi pada semester pertama (Lely, 2013) terbukti secara signifikan berpengaruh terhadap daya tahan kelanjutan studi mahasiswa.

Dari hasil penelitian tersebut, hal yang menarik untuk dikaji lebih lanjut adalah bagaimana keterkaitan peubah-peubah yang signifikan mempengaruhi daya tahan mahasiswa melanjutkan studi pada Jurusan Tadris matematika secara struktural. Dari analisis ini dapat diketahui peubah mana yang paling kuat mempunyai asosiasi dengan daya tahan mahasiswa melanjutkan studi pada jurusan tadris mamtematika. Analisis statistik yang dapat menjelaskan keterkaitan secara 
struktural peubah pada data kategorik dengan bentuk data cacahan adalah metode CHAID. Dalam penelitian ini, analisis CHAID diterapkan dalam menentukan segmentasi mahasiswa dengan status drop out atau mengundurkan diri pada jurusan tadris Matematika. Tujuan segmentasi ini adalah mengidentifikasi mahasiswa yang memiliki kemungkinan harapan drop out atau mengundurkan diri dari jurusan tadris Matematika IAIN Batusangkar.

Metode CHAID (Chi-square Automatic Interaction Detection) adalah salah satu tipe dari metode AID (Automatic Interaction Detection), yaitu metode yang digunakan untuk menganalisis keterkaitan struktural antara peubah dalam segugus data (Fielding, 1977). Hasil CHAID adalah pohon keputusan dendrogram yang didasari oleh Khi-kuadrat yang dibangun oleh pemisahan kelompok bagian secara berulang-ulang menjadi dua atau lebih anak cabang. Untuk memperoleh pemisahan terbaik pada semua cabang, pasangan kategori peubah penjelas dapat digabung sampai tidak ada kategori yang tidak nyata

Tujuan penelitian ini adalah untuk mengetahui keterkaitan struktural peubah yang signifikan mempengaruhi daya tahan mahasiswa melanjutkan studi pada jurusan tadris matematika.

\section{METODE PENELITIAN}

Dalam penelitian ini digunakan data sekunder yang diperoleh dari hasil rekap data mahasiswa Tadris matematika yang berhenti studi oleh bagian Akademik Kemahasiswaan dan Jurusan. Berhenti studi dalam hal ini didefinisikan sesuai dengan peraturan akademik STAIN Batusangkar Pasal 34 mengenai evaluasi kelangsungan studi dan pengunduran diri atas inisiatif sendiri. Data yang digunakan adalah seluruh mahasiswa jurusan Tadris Matematika yang terdaftar dari tahun 2008 sampai dengan tahun 2012. Variabel dalam penelitian ini terdiri dari variabel dependent dan independen sebagai berikut:
Variabel dependent dalam penelitian ini adalah status mahasiswa dengan kategori biner, bertahan (0) dan tidak bertahan atau drop out ataupun mengundurkan diri dari jurusan tadris Matematika (1). Peubah ini diukur semenjak mahasiswa terdaftar sebagai mahasiswa jurusan tadris Matematika secara akademis, sampai terjadi perubahan status (DO/ tidak DO) selama kurun waktu 3 (tiga) tahun atau 6 (enam) semester. Mahasiswa dikatakan tidak bertahan jika status akademik mahasiswa mengalami perubahan dari mahasiswa aktif menjadi tidak aktif (DO/ mengundurkan diri) atau pindah jurusan. Sedangkan mahasiswa mahasiswa dikatakan bertahan jika mahasiswa aktif dalam kurun waktu tersebut di atas.

Variabel independent (X) dalam penelitian ini diantaranya (1) Asal sekolah menengah, pengkategorian asal sekolah menjadi SMA, MA dan SMK; (2) Jurusan pada sekolah menengah, pengkategorian jurusan pada sekolah menengah adalah IPA, IPS dan kejuruan; (3) Usia, dengan kategori usia $<18$ tahun, usia 18 tahun dan usia > 18 tahun; (4) Indeks prestasi semester pertama; (5) Jalur masuk perguruan tinggi dengan kategori tes dan undangan dan (6) Nilai kalkulus I dengan kategori lulus (dengan nilai $A, A^{-}, B^{+}, B, B^{-}, C^{+}, C$ ), mengulang (dengan nilai $D$ ) dan gagal (dengan nilai $E$ ).

Magidson dalam Bagozzi (1994), menerangkan bahwa langkah-langkah analisis CHAID secara garis besar dapat dibagi menjadi tiga tahap, yaitu Penggabungan, Pemisahan dan Penghentian. Tahap-tahap tersebut dapat dijabarkan sebagai berikut :

\section{Tahap 1: Penggabungan}

Untuk tiap variabel independen, $\mathrm{X}_{1}, \mathrm{X}_{2}, \ldots \mathrm{X}_{\mathrm{k}}$

Bentuk tabel kontingensi dua arah dengan variabel dependennya.

- Hitung statistik chi-square untuk setiap pasang kategori yang dapat dipilih untuk digabung menjadi satu, untuk menguji kebebasannya dalam sebuah sub tabel kontingensi 2xJ yang dibentuk oleh sepasang kategori tersebut dengan variabel dependennya yang mempunyai sebanyak $\mathbf{J}$ kategori.

- Untuk masing-masing nilai chi-square berpasang-an, hitung p-value berpasangan 
bersamaan. Di antara pasangan pasangan yang tidak signifikan, gabungkan sebuah pasangan kategori yang paling mirip (yaitu pasangan yang mempunyai nilai chi- square berpasangan terkecil) menjadi sebuah kategori tunggal, dan kemudian dilanjutkan ke langkah nomor 4. Tetapi apabila semua pasangan kategori yang tersisa adalah signifikan, lanjutkan ke langkah nomor 5 .

- Untuk suatu kategori gabungan yang terdiri dari 3 kategori atau lebih, ujlah untuk melihat apakah suatu kategori variabel independen seharusnya dipisah dengan menguji kesignifikanan antara kategori tersebut dengan kategori yang lain dalam satu kategori gabungan. Jika didapat nilai chi- square yang signifikan, pisahkan kategori tersebut dengan yang lain. Jika lebih dari satu kategori yang bisa dipilih untuk dipisah, pisahkan salah satu yang mempunyai nilai chi-square tertinggi. Kemudian kembali ke langkah nomor 3.

- Dengan cara memilih, gabungkan suatu kategori yang mempunyai sedikit pengamatan yang tidak sesuai dengan kategori lain yang paling mirip, seperti yang diukur oleh nilai chi-square berpasangan yang terkecil.

- Hitung $p$-value terkoreksi Bonferroni didasarkan pada tabel yang telah digabung.

\section{Tahap 2: Pemisahan}

Pilihlah variabel independen terbaik, yaitu variabel independen dengan nilai $p$-value yang terendah, dan kemudian melakukan pembagian kelompok dengan variabel independen ini (yaitu gunakan masing-masing kategori-kategori variabel inde- penden tersebut, yang telah digabung secara optimal, untuk menentukan sub pembagian dari kelompok induk menjadi sub kelompok yang baru). Jika tidak ada variabel independen dengan nilai $p$-value yang signifikan, jangan memulai pembagian kelompok tersebut.

\section{Tahap 3: Penghentian}

Kembali ke langkah nomor 1 untuk menganalisis sub kelompok berikutnya. Hentikan ketika semua sub kelompok telah dianalisis dan juga telah berisi pengamatan-pengamatan dengan jumlah yang terlalu sedikit.
Hasil pembentukan segmen dalam CHAID akan ditampilkan dalam sebuah diagram pohon. Diagram pohon CHAID mengikuti aturan "dari atas ke bawah" (Top-down stopping rule), di mana diagram pohon disusun mulai dari kelompok induk, berlanjut di bawahnya sub kelompok yang berturutturut dari hasil pembagian kelompok induk berdasarkan kriteria tertentu (Myers, 1996). Tiaptiap node dari diagram pohon ini menggambarkan sub kelompok dari sampel yang diteliti. Setiap node akan berisi keseluruhan sampel dan frekuensi absolut $n_{i}$ untuk tiap kategori yang disusun di atasnya

Dengan demikian pada penelitian ini tahapan analisis CHAID dapat dilakukan dengan langkah sebagai berikut (1) Memasukkan semua data berdasarkan kategori yang ditentukan seperti di Tabel 1; (2) Menentukan terlebih dahulu semua skala variabel yang akan digunakan dengan tepat dan benar; (3) Menentukan kategori target dari kategori-kategori variabel dependen. Hal ini dilakukan untuk memunculkan beberapa grafik lain sebagai informasi lebih lanjut dalam data yang ada. Kategori target yang dipergunakan bisa salah satu atau semua kategori yang ada pada variabel dependen; (4) Selanjutnya akan dilanjutkan dengan proses matematis analisis CHAID sesuai prosedur analisis CHAID, yaitu langkah Penggabungan, Pemisahan, dan Pemberhentian. Dalam langkah Penggabungan akan mulai diterapkan uji chi-square dan pengali Bonferroni sebagai pengoreksinya. Pada langkah Penggabungan sebagian besar proses akan menggunakan uji chi-square saja. Kemudian dilakukan iterasi pada kedua langkah tersebut, dan proses iterasi akan berhenti apabila sudah tidak ada lagi variabel independen yang tersisa untuk diuji hubungannya dengan variabel dependen, atau juga apabila terbentuknya node pada diagram pohon telah memenuhi batasan yang ditentukan oleh peneliti. Proses ini disebut dengan proses Pemberhentian; (5) Menentukan segmentasi mahasiswa dengan meng- interpretasikan diagram pohon CHAID dan (6) Menentukan klasifikasi mahasiswa berdasarkan hasil segmentasi status mahasiswa yang sudah terbentuk.

\section{HASIL DAN PEMBAHASAN}


Analisis CHAID menghasilkan suatu dendogram dibantu dengan pengggunaan software SPSS versi 17.0, menggambarkan pengelompokkan berdasarkan hubungan berstruktur peubah respon dengan peubahpeubah penjelas. Proses pengelompokkan dengan menggunakan metode CHAID ini menggunakan default batas nilai- $\mathrm{p}=0.5$, artinya jika terdapat dua kategori/ kelompok yang memiliki nilai-p $\geq 0.5$, maka kategori/ kelompok tersebut digabungkan. Sedangkan untuk splitting, menggunakan default nilai-p < 0.10. Dendogram hasil pemisahan analisis CHAID dapat dilihat dari Gambar 2.
Diagram pohon yang dihasilkan analisis CHAID pada Gambar 1, menerangkan bahwa pada note teratas diketahui jumlah mahasiswa yang dimasukkan kedalam analisis adalah 260, terdiri dari 217 mahasiswa (83.6\%) dengan satus bertahan dan 43 mahasiswa (16.6\%) dengan status drop out atau mengundurkan diri.

Tahap pertama dari analisis CHAID adalah tahap penggabungan. Dalam penelitian ini, variabel bobot nilai Kalkulus I dibagi menjadi tiga kategori yaitu Lulus (dengan nilai $A, A^{-}, B^{+}, B, B^{-}, C^{+}, C$ ); Mengulang (dengan nilai D) dan Gagal (dengan nilai E).

Tabel 1. Tabulasi Kategori Tiap Variabel

\begin{tabular}{llc}
\hline \multicolumn{2}{c}{ Variabel Dependen } & Kategori \\
\hline Status mahasiswa & & 0 \\
1. Bertaahan & & 1 \\
2. Tidak Bertahan & Kategori \\
\hline \multicolumn{2}{c}{ Variabel Independen } & \\
\hline Asal sekolah Menengah & 1 \\
1. SMA & 2 \\
2. MA & 3 \\
3. SMK & \\
\hline Jurusan & 1 \\
1. IPA & 2 \\
2. IPS & 3 \\
3. DLL & 1 \\
\hline Jalur masuk PT & 2 \\
1. Tes & \\
2. Undangan & 1 \\
\hline Usia masuk PT & 2 \\
1. 18 th & 3 \\
2. < 18 th & \\
3. > 18 th & 1 \\
\hline Indeks Prestasi SMT I & \\
1. IP < 2.00 & 3 \\
2. IP 2.00-3.00 & \\
3. IP $>3.00$ & 1 \\
\hline Nilai Kalkulus I & \\
1. Lulus & \\
2. Mengulang & \\
3. Gagal & \\
\hline
\end{tabular}




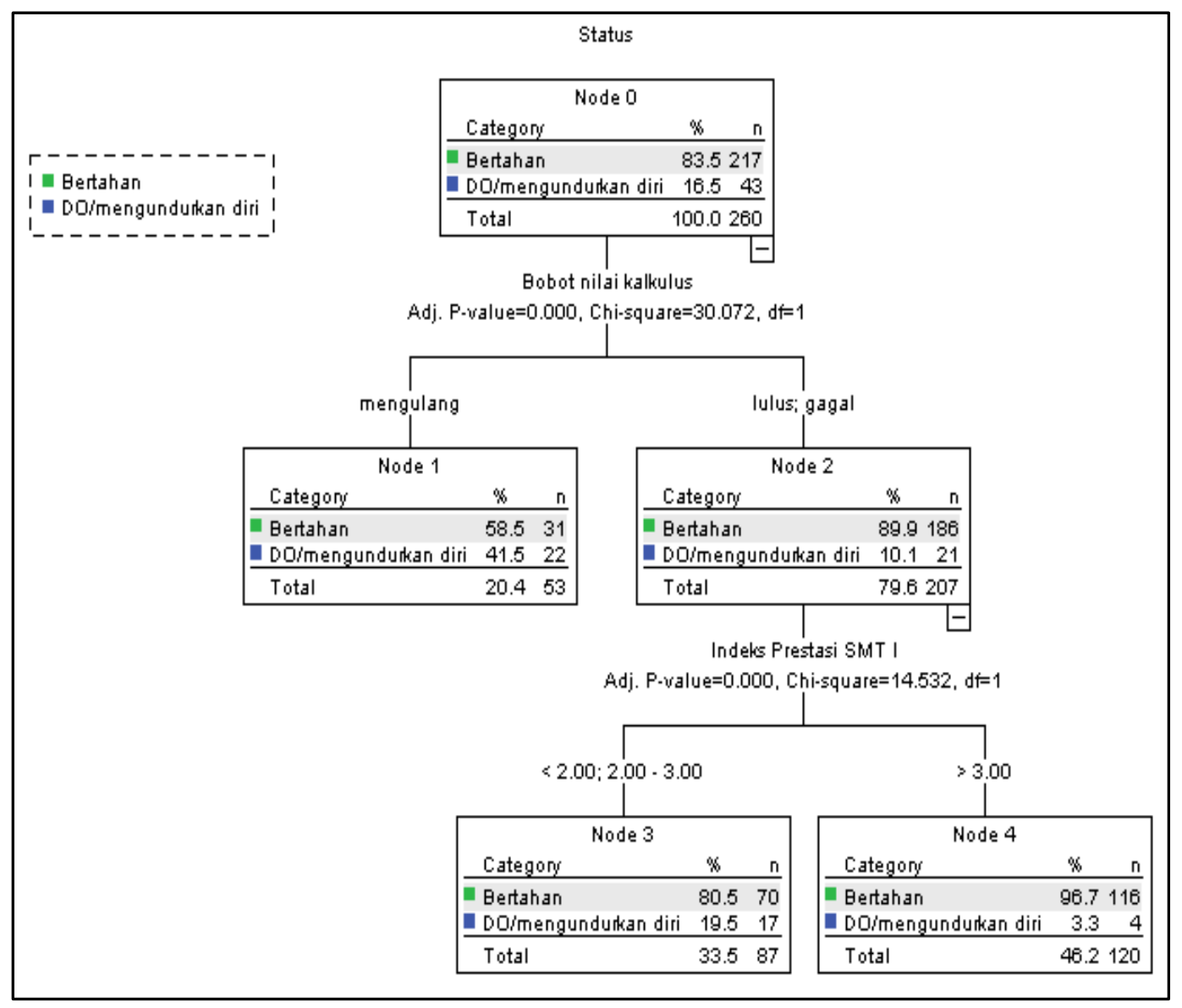

Gambar 1. Dendogram / Diagram Pohon analisis CHAID

Setelah melalui analisis CHAID, variabel ini diiringkas menjadi 2 kategori, seperti yang terlihat pada dendogram CHAID pada Gambar 1 yaitu Kategori mengulang (dengan nilai D); Kategori lulus (dengan nilai $\left.A, A^{-}, B^{+}, B, B^{-}, C^{+}, C\right)$ digabung dengan kategori Gagal (dengan nilai E).

Hal ini berarti kategori 1 dan 3 memenuhi syarat kesignifikanan chi-square untuk bisa digabungkan menjadi satu kategori tunggal atau dengan kata lain dari tiga kategori nilai mata kuliah Kalkulus I yang ada, diperoleh dua kategori baru yang berbeda secara statistik yaitu mahasiswa dengan kategori nilai mengulang dan mahasiswa dengan kategori lulus dan gagal.

Penggabungan kategori juga terjadi pada peubah indeks prestasi pada semeter pertama.
Dalam penelitian ini, peubah IP pada semester pertama dibagi menjadi tiga kategori, yaitu 1 . IP < 2.00; 2. IP 2.00 - 3.00; 3. IP > 3.00. Selanjutnya peubah ini pada analisis CHAID diringkas menjadi 2 kategori yaitu Kategori IP $<2.00$ digabung dengan kategori IP 2.00-3.00; Kategori IP > 3.00.

Hal ini berarti kategri 1 dan 2 memenuhi syarat kesinifikanan chi-square untuk bisa digabungkan menjadi satu kategori tunggal dengan kata lain dari ketiga kategori IP mahasiswa, diperoleh dua kategori yang berbeda secara statistik yaiti mahasiswa dengan kategori IP $<3.00$ dan kategori mahasiswa dengan IP $>3.00$.

Dari Tabel 3, dapat diketahui bahwa dari 6 variabel penjelas yang dimasukkan dalam analisis, terdapat 2 variabel penjelas yang 
terbukti signifikan terhadap variabel terikat, yaitu peubah nilai pada mata kuliah kalkulus I dan variabel Indeks Prestasi pada semester I. Hal ini juga terlihat dari dendogram CHAID yang menghasilkan 3 pemisahan atau 3 kedalaman, dimana peubah nilai pada mata kuliah Kalkulus I membagi status mahasiswa pada kedalaman I, kemiudian peubah Indeks prestasi pada semester I pada kedalaman ke- 2 . Terdapat 4 peubah penjelas yang tidak terbukti secara signifikan mempunyai asosiasi dengan peubah terikat atau daya tahan mahasiswa melanjutkan studi pada jurusan tadris Matematika yaitu peubah sal sekolah menengah, jalur masuk Perguruan Tinggi, Usia masuk Perguruan Tinggi, jurusan pada sekolah menengah.

Nilai P-value dan nilai uji chi-square dari masing-masing peubah penjelasyang terbukti mempunyai asosiasi dengan peubahan status daya tahan mahasiswa melanjutkan studi pada jurusan Tadris Matematika dapat diringkas pada Tabel 2.

Tabel 2. P-Value dan Chi-Square Peubah Penjelas

\begin{tabular}{lll}
\hline Variabel & P-value & Chi-Square \\
\hline Nilai Mata Kuliah Kalkulus I & 0.000 & 30.072 \\
Indeks Prestasi Semester I & 0.000 & 14.632 \\
\hline
\end{tabular}

Nilai P-value pada Tabel 2 merupakan nilai P-value setelah dikoreksi oleh pengali Bonferroni. Dari Tabel 2 dapat diketahui bahwa apabila dilakukan pengambilan keputusan berdasarkan P-value, dimana kedua nilai tersebut kurang dari $\alpha=0.05$, maka dapat ditarik kesimpulan bahwa keputusan uji chisquare adalah tolak $H_{0}$ atau terdapat asosiasi antara kedua peubah tersebut terhadap peubah status daya tahan mahasiswa melanjutkan studi.

Pada Gambar 1 juga dapat dilihat bahwa peubah nilai pada mata kuliah Kalkulus I adalah peubah penjelas yang memiliki asosiasi paling kuat dengan daya tahan mahasiswa melanjutkan studi, atau dapat juga dijelaskan bahwa peubah ini merupakan peubah terbaik yang digunakan untuk membagi dan menerangkan peubah daya tahan mahasiswa melanjutkan studi pada jurusan Tadris Matematika. Kemudian dilanjutkan oleh peubah Indeks Prestasi pada semester I, merupakan peubah penjelas yang signifikan membagi kategori pada node ke-2 (kategori IP < 3.00) pada peubah nilai pada mata kuliah Kalkulus I.

Apabila dilihat secara keseluruhan, dendogram pada Gambar 1 menghasilkan 3 segmentasi terhadap pilihan daya tahan mahasiswa melanjutkan studi pada jurusan tadria Matematika dituliskan di Tabel4.

Tabel 4. Segmentasi CHAID

\begin{tabular}{ccl}
\hline Segmen Ke & Node & \multicolumn{1}{c}{ Karakteristik Mahasiswa } \\
\hline 1 & Node 1 & Mengulang pada Kalkulus I \\
\hline 2 & Node 2, node 3 & $\begin{array}{l}\text { Lulus atau gagal pada mata kuliah Kalkulus I } \\
\text { dengan IP semester I <3.00 }\end{array}$ \\
\hline 3 & Node 2, Node 4 & $\begin{array}{l}\text { Lulus atau gagal pada mata kuliah Kalkulus I } \\
\text { dengan IP semester I }>3.00\end{array}$ \\
\hline
\end{tabular}

Dari ketiga segmen yang terbentuk, dapat tidak bertahan dalam melanjutkan studi pada ditabulasi jumlah dan persentase masing- jurusan tadris Matematika. masing mahasiswa yang bertahan dan yang 
Tabel 5. Tabulasi Jumlah dan Persentase Mahasiswa yang Bertahan dan yang Drop Out/ mengundurkan diri.

\begin{tabular}{ccccc}
\hline Segmen ke- & Jumlah bertahan & Persentase & Jumlah DO/ mengundurkan diri & Persentase \\
\hline 1 & 31 & $68.6 \%$ & 22 & $41.5 \%$ \\
2 & 70 & $80.5 \%$ & 17 & $19.5 \%$ \\
3 & 116 & $96.7 \%$ & 4 & $3.3 \%$ \\
\hline
\end{tabular}

Pada kasus yang dibahas dalam penelitian ini, apabila kita ingin memprediksi mahasiswa dengan kemungkinan terbesar tidak mampu bertahan melanjutkan studinya pada jurusan Tadris Matematika adalah mahasiswa dengan karakteristik pada segmentasi I $(41.5 \%)$ yaitu mahasiswa yang mengulang pada mata kuliah Kalkulus I. Hal ini dapat dipahami, karena mata kuliah Kalkulus I merupakan mata kuliah keahlian dasar yang ditawarkan pada semester pertama sekaligus mata kuliah prasyarat untuk sebagian besar mata kuliah selanjutnya pada jurusan tadris Matematika, sehingga ketika mahasiswa mendapatkan nilai yang mengharuskan mereka mengulang (nilai $\mathrm{C}$ dan D), kemungkinan materi dasar dari matematika tidak mereka kuasai dengan baik dan ini akan berakibat tertundanya studi mahasiswa bahkan sampai tidak mampu melanjutkan studi.

Persentase yang cukup besar dari mahasiswa drop out atau mengundurkan diri juga terdapat pada segmen yang ke-2 (19.5\%) dengan karakteristik mahasiswa yang gagal pada mata kuliah Kalkulus I dan memiliki IP semester I < 3.00. Jadi, dapat dikatakan bahwa performan mahasiswa pada semester pertama dapat menjadi tolak ukur bagi mahasiswa jurusan tadris matematika untuk mampu bertahan atau tidak dalam melanjutkan studinya pada prodi yang dimaksud. Sehingga ini dapat menjadi masukkan kepada jurusan agar mengintensifkan pembelajaran pada semester pertama, seperti mengadakan kegiatan tutorial pada matakuliah-matakuliah yang menjadi keahlian dasar bagi mahasiswa jurusan tadris Matematika.

\section{KESIMPULAN}

Berdasarkan uraian pada penelitian ini dapat diambil kesimpulan bahwa nilai pada mata kuliah Kalkulus I merupakan peubah penjelas yang paling kuat mempunyai asosiasi dengan daya tahan mahasiswa melanjutkan studi, dilanjutkan oleh peubah Indeks Prestasi pada semester I. Metoda CHAID pada analisis faktor yang mempengaruhi daya tahan mahasiswa melanjutkan studi menghasilkan tiga segmentasi. Persentase mahasiswa terbesar yang tidak mampu bertahan melanjutkan studi merupakan karakteristik mahasiswa pada segmen I, yaitu mahasiswa yang mengulang pada mata kuliah Kalkulus I. kemudian dilanjutkan pada karakteristik mahasiswa pada segmen 2, yaitu mahasiswa yang gagal pada mata kuliah kalkulus I dan mempunyai IP semester I $<3.00$.

Hasil penelitian ini dapat menjadi masukkan bagi jurusan, bahwa performan mahasiswa jurusan tadris Matemateika pada semester awal dapat menjadi tolak ukur mampu atau tidaknya mahasiswa dalam bertahan melanjutkan studinya, sehingga dapat dilakukan usaha meningkatkan performan mahasiswa tersebut dengan mengintensifkan pembelajaran pada semester awal seperti mengadakan kegiatan-kegiatan tutorial pada mata kuliah keahlian dasar pada jurusan tadris Matematika.

\section{DAFTAR KEPUSTAKAAN}

Bagozzi RP. 1994. Advanced Methods of Marketing Research. Oxford: Blackwell Publishers Ltd. 
Kurnia, L. 2016. Analisis Daya Tahan Mahasiswa dalam Melanjutkan Studi dengan Chi-Squared Automatatic Interaction Detection. Journal of Sainstek. 8(1):56-63

Fielding A. 1977. Binary Segmentation: The Automatic Interaction Detector and Related Tecnique for Exploring Data Structure. London, New York, Sidney, Toronto: John Wiley \& Sons.

Lely K. 2013. Pemodelan Faktor yang Mempengaruhi Mahasiswa Berhenti
Studi pada Jurusan Tadris Matematika STAIN Batusangkar. (Penelitian tidak dipublikasikan). Batusangkar: P3M STAIN Batusangkar.

Myers JH. 1996. Segmentation and Positioning for Strategic Marketing Decisions. Chicago: American Marketing Association. 